\title{
Corrigendum
}

\section{Brain Serotonin Function in MDMA (Ecstasy) Users: Evidence for Persisting Neurotoxicity}

\author{
Margaret M Benningfield and Ronald L Cowan
}

Neuropsychopharmacology (20 I3) 38, 907; doi: I0.1 038/npp.20I2.257

Correction to: Neuropsychopharmacology Reviews (2013) 38, 253-255; doi:10.1038/npp.2012.178

In this article, Dr Benningfield and Dr Cowan have been funded by the NIH via grants R01 DA015137, R21 DA020149
(NIDA), and R21 MH073800 (NIMH) to Dr Cowan; grant K12 DA00357 to Dr Benningfield (NIDA/AACAP); and the Vanderbilt Clinical and Translational Science Award UL1TR000445 (NCRR). 